\title{
Okul Müdürlerinin Performans Değerlendirme Sürecine İlişkin Öğretmen Algıları Ölçeği
}

\author{
DOI: 10.26466/opus. 801411
}

*

\author{
Ayșe Hünerli* - Meltem Acar Güvendir** \\ * Okul Öncesi Öğretmeni, Kızılpınar Atatürk İlkokulu, Tekirdağ/Türkiye \\ E-Posta: aysehunerli@gmail.com \\ ORCID: 0000-0003-0353-4959 \\ **Doç. Dr.,Trakya Üniversitesi, Eğitim Fakltesi, Edirne/ \\ E-Posta: meltemacar@gmail.com \\ ORCID: $\underline{0000-0002-3847-0724}$
}

$\ddot{O} z$

$B u$ araştırmanın amacl, okul müdürlerinin performans değerlendirme sürecine ilişkin öğretmen algılarını belirlemeye yönelik geçerli ve güvenilir bir ölçme aracı geliştirmektir. Araştırmanın çalışma grubunu, 2015-2016 eğitim öğretim yılında Tekirdă̆ ili Çerkezköy ilçesinde görev yapan 537 öğretmen oluşturmaktadır. Öğretmenlerin kişisel özelliklerini belirlemek amacıyla bilgi formu hazırlanmıştır. Bilgi formu ile birlikte sunulan ölçme aracı 70 maddeden oluşmaktadır. Çalışmada öncelikli olarak elde edilen verilerin örneklem büyüklü̈̆̈̈nün yeterliği için, Kaiser Meyer Olkin (KMO) katsayısı ve çok değişkenli normallik kontrolü için, Bartlett testi kullanılmıştır. KMO katsayısı .93 ve Barlett testi anlamlı bulunmuştur. Bu durumda açımlayıcı faktör analizinin varsayımları sağlanmıştır. Ölçeğgin faktör yapısını ortaya koyabilmek için açımlayıcı ve doğrulayıcı faktör analizleri yapılmıştır. Ölçeğin açımlayıcı faktör analizi sürecinde ölçekte yer alan maddelere temel bileşenler analizi ve dik döndürme tekniği uygulanmıştır. Varimaks dik döndürme tekniği kullanılarak faktör yükleri .40'ın altında olan ve birden fazla faktörde birbirine yakın faktör yükleri veren 10 madde ölçekten çıkartılmıştır. Elde edilen faktör yapısını başka bir grup üzerinde doğrulamak amacıyla yapılan doğrulayıcı faktör analizinde elde edilen uyum iyiliği değerleri, yeterli uyuma işaret etmektedir. Madde-toplam korelasyonlarının 66 ile .90 oranında değiş̧tiği saptanmıştır.Ölçeğin bütününe ait Cronbach alfa iç tutarlık güvenirlik katsayıları birinci faktörden altıncı faktöre doğru sırasıyla $.95, .94, .95, .94, .93$ ve .90 'dır. Sonuç olarak, okul müdürlerinin performans değerlendirme sürecine ilişkin öğretmen algılarmı belirlemeye yönelik, geçerliliği ve güvenirliği kanıtlanmış toplamda altı faktörlü ve 60 maddeden oluşan bir ölçek elde edilmiştir.

Anahtar Kelimeler: Performans, performans değerlendirme, öğretmen performans değerlendirme, okul müdürü, ölçek geliştirme. 


\title{
Teacher Perceptions Scale of School Principals on Performance Evaluation
}

*

\begin{abstract}
The aim of this study is to develop valid and reliable evaluation method for performance evaluation process in order to assess teacher perceptions by school principals. The study was conducted on 537 teachers from 2015-2016 academic year in Cerkezkoy, Tekirdag. In order to determine teachers' individual skills and characteristics, an information survey was prepared. The measurement tool developed consists of 70 items. Kaiser Meyer Olkin (KMO) coefficient was used for the sufficiency of the sample size of the data obtained in the study, and Bartlett test was used for multivariate normality control.KMO coefficient was found to be .93 and Barlett test was found to be significant.In this case, the assumptions of the exploratory factor analysis are provided.Exploratory and confirmatory factor analyzes were conducted to reveal the factor structure of the scale.During the exploratory factor analysis process of the scale, principal component analysis and vertical rotation technique were applied to the items in the scale. Using the Varimax vertical rotation technique, 10 items with factor loads below 40 and values close to each other were removed from the scale. The goodness of fit values obtained in the confirmatory factor analysis performed to verify the obtained factor structure on another group indicate sufficient fit. The item-total correlations ranged between .66 and .90. The Cronbach alpha internal consistency and reliability coefficients of the whole scale were .95, .94, .95, .94, .93, and 90 from the first factor to the sixth factor, respectively. As a result, the validated and reliable scale consisting of 6 factors and 60 items has been developed and used to determine teacher perceptions of school principals for the performance evaluation process.
\end{abstract}

Keywords: Performance, performance evaluation, performance evaluation of teacher, school manager, school manager, scale development. 


\section{Giriş}

Bireyler, toplumsal yaşamın bir gerekliliği olarak sürekli birbirleriyle etkileşim halindedir. Bilgilerini paylaşmayı öğrenen bireyler zaman içinde ihtiyaç ve isteklerini karşılamak amacıyla birlikte yaşamaya ihtiyaç duymaktadırlar. Toplum içinde oluşan bu insan ilişkileri ağını belirli çerçevede ve düzende tutan sistemlere gerek duyulmaktadır. Bu sistemlerden bir tanesi de eğitim sistemidir. Eğitim; sosyal ve toplumsal bir varlık olan insanı, hayatın koşullarına hazırlama ve bireylerden en faydalı şekilde yararlanma adına yapılan bilgilendirme ve yönlendirme örüntüsüdür. Toplum için faydalı bireyler yetiştirme sürecinde; eğitim öğretim kurumlarına, yöneticilere, müfettişlere ve en çok da öğretmenlere mühim görev ve sorumluluklar yüklenmektedir. Bu önemli süreçte, öğretmenlerin öğrencilerine daha faydalı olabilmesi için mesleki bilgilerinden farklı olarak meslekte daha tecrübeli kişilerin fikirlerine ve yardımlarına ihtiyaç duymaktadırlar. Bununla birlikte eğitim öğretim sürecinin iyileştirilmesi adına öneri, düzeltme ve değerlendirme, takdir ve ödüllendirmenin gerekliliği şarttır. Eğitim öğretim sürecinde öğretmenler görevlerini yerine getirirken, durum değerlendirmesi yapmaları ve öz değerlendirme yapabilmeleri adına müfettişlere en çok da okul yöneticilerine önemli görevler düşmektedir (Fırıncıoğulları Bige, 2015).

Türkiye' de eğitimde denetim faaliyetleri öğretmen ve kurum denetimi olmak üzere iki farklı şekilde yapılmaktadır. İki uygulama, yıllardır müfettişler (denetmenler, denetçiler ve maarif müfettişi) tarafından yürütülmüştür (Balyer, 2012). Eğitim kurumlarında denetim esasları, Milli Eğitim Bakanlığı Rehberlik ve Denetim Başkanlığı ile Maarif Müfettişleri Başkanlığ Yönetmeliğine göre üç yıllık çalışma programı ve yıllık faaliyet planı ile belirlenir. Başkanın teklifi, bakanın onayı ve müsteşarın görüşü ile uygulamaya konulan denetim planı, her yıl değerlendirilir. Türkiye'de öğretmenlerin ders denetimleri maarif müfettişleri ve okul müdürlerince yapılmaktadır. Milli Eğitim Bakanlığı İlköğretim Müfettişleri Başkanlıkları ve Teftiş Yönergesinde müfettişlerin kurumlarda; kurum teftişi ile seminer ve kurs teftişi yapmakla görevlendirildikleri belirtilmiştir. Kurum teftişi; yönetici, öğretmen ve okulda görevli diğer personel teftişi olarak gruplandırılmıştır. Ancak 24.05.2014 tarihinde yürürlüğe giren 652 sayılı Kanun Hükmünde 
Kararnamenin ilgili maddesinde müfettişlerin öğretmen denetiminden söz edilmemiştir. Kurum denetimleri müfettişler tarafından yapılacak; ancak müfettişler gerekli gördükleri zamanlar dışında, öğretmenlere ders denetimi yapamayacaklardır. Bu durum, okul müdürlerinin eskiden beri var olan ders denetimi görevinin önemini arttırmıştır (Kış ve Yeşil, 2015). 17 Nisan 2015 tarihinde Resmî Gazete'de yayınlanarak yürürlüğe giren, yayınlanmasıyla birlikte ciddi değişiklikler getiren Millî Eğitim Bakanlığ Atama ve Yer Değiştirme Yönetmeliği içinde yer alan Öğretmen Performans Değerlendirme Hükmü, 2015-2016 Eğitim-Öğretim yılı sonundan itibaren uygulanmaya başlamıştır.

Okul müdürleri performans değerlendirmesi yaparken 10 ana başlık altında 50 soruluk ölçütlere derecelendirme yaparak öğretmen değerlendirmesini puanlayabilmektedir. Ölçütlere verilebilecek cevaplar şu şekildedir; hiçbir zaman 0 puan; nadiren 0,5 puan; bazen 1 puan; sıklıkla 1,5 puan: her zaman 2 puan (Millî Eğitim Bakanlığı, 2015). 50 soruluk ölçütlerin hepsine tam puan verilirse 100 puana ulaşılmaktadır. Ölçütlere verilen cevaplardan alınan puanlar öğretmenin performans notunu ortaya çıkarmaktadır. Bu performans değerlendirme sistemi 20172018 eğitim öğretim yılında askıya alınmıştır.

Okul müdürleri, görev yaptığı okullardaki eğitim ve öğretimin daha nitelikli olabilmesi için, belirlenen kurallar, yönetmelikler ve yasalar gereğince birinci derecede sorumlu kişilerdir. Bununla birlikte, örgüt yönetimindeki yeni yaklaşımlar, öğretme ve öğrenme anlayışındaki esneklik, yaratıcılık, çeşitlilik, öğrenci odaklı öğretim gibi öğelerin önem kazanmasıyla okul müdürlerinin rolleri şekillenmiş ve görevleri artmıştır. Okul müdürlerinin; yasalar ve yönetmelik gereğince planlama yapma, bütçe gibi idari işler, örgütü amaçlar doğrultusunda güdüleme, demokratik bir okul iklimi oluşturma, örgüt üyelerini iş birliği içinde çalışmaya sevk etme gibi önemli görevleri bulunmaktadır (Allen, 1998; Murphy ve Shipman, 1998; Akt. Özmen ve Batmaz, 2014). Okul müdürlerinden, öğretim lideri olmaları beklentisi, başarılı ve etkili bir okul için okul müdürüne düşen görevler; denetim kavramının rehberlik ve geliştirme süreci olarak görülmesi, öğretmenleri denetleyecek müfettiş sayısının yetersiz olması gibi çeşitli nedenler öğretmen performansının okul müdürleri tarafından değerlendirilmesi gerekliliğini kanıtlar niteliktedir. Okul müdürlerinin; öğretmenleri müfettişlerden daha iyi 
tanımaları, öğretmenlerin hangi konularda geliştirilmesi gerektiğini bilmeleri, aynı ortamda bulundukları için ders içi ve ders dışı yaptıkları eğitim faaliyetlerden haberdar olmaları gibi sebepler öğretmen performans değerlendirmesinin okul müdürleri tarafından yapılması nedenleri arasında sayılmaktadır (Yılmaz,2009).

Dünyadaki öğretmen performans değerlendirme sistemleri incelendiğinde İngiltere'de öğretmen değerlendirmesinde profesyonel denetçilerin yanında okul yöneticileri, veliler ve öğrencilerin görüşlerine de önem verilir. Bunların yanında öğretmenin kendisini değerlendirmesi de istenir. Öğretmen değerlendirmesi yapılırken birden fazla kaynaktan bilgi alınmasına rağmen profesyonel denetçilerin ve okul yöneticilerinin değerlendirmesine daha çok önem verilmektedir (Meşeci,2007). Kanada'da öğretmenlerin değerlendirilmesinden okul kurulları sorumludur. Öğretmenler Eğitim Bakanlığı tarafından oluşturulmuş davranış kurallarından sorumlulardır. Mesleğe yeni başlayan öğretmenler, genellikle öğretmenliğin ilk yıllarında okul müdürünün programlı denetimleri ile değerlendirilir (Alberta Learning, 2003). Güney Kore'de öğretmen değerlendirme sistemi birbirinden bağımsız olarak çalışan, farklı amaçlara sahip olan üç farklı değerlendirmeyi bünyesinde barındırmaktadır. Birincisi, performans yönetimi değerlendirmesi, öğretmen hesap verebilirliği için kullanılır, kariyer ve tanıtım fırsatlarıyla ilgili kararları alır. İkincisi, birden fazla ölçüme dayanan mesleki gelişim değerlendirmesi, (akranlar ve okul liderleri tarafından yapılan sınıf gözlemleri, öğrenci ve ebeveyn anketleri) bireysel ve okul çapında öğretmen profesyonel gelişimi için kullanılır. Üçüncüsü, performansa dayalı bir teşvik programı, öğretmenleri belirli çıtı veya rollerin başarısı için ödüllendirir (Dippenaar vd., 2015; Akt. Gür Erdoğan ve Horzum, 2019). Finlandiya ulusal ve resmi bir okul yönetimine ve öğretmen değerlendirmesine sahip değildir. Öğretmen performans değerlendirme prosedürleri yerel düzeyde olup, öncelik olarak okul yönetiminin takdirine bağlı şekilde gelişir. Çoğunlukla öğretmenler ile okul yöneticileri arasındaki rutin toplantılar ve eğitimi geliştirmek için yapılan tartışmalar yaygındır. Yerel düzeyde okul yöneticileri öğretmen değerlendirmeleri yapsa da her okul bireysel değerlendirme çerçevesinde tasarlanmıştır (OECD, 2015). 
Araştırmanın amacı, 2015-2016 eğitim ve öğretim yılı sonunda uygulanmaya başlanılan okul müdürlerinin, öğretmen performansını değerlendirmesi üzerine öğretmen algılarını ölçmek için bir ölçme aracı geliştirmektir. Bu amaç doğrultusunda iki alt amaca cevap aranmıştır:

1. Okul Müdürlerinin Performans Değerlendirme Sürecine İlişkin Öğretmen Algıları Ölçeği öğretmen algılarını güvenilir biçimde ölçmekte midir?

2. Okul Müdürlerinin Performans Değerlendirme Sürecine İlişkin Öğretmen Algıları Ölçeği öğretmen algılarını geçerli biçimde ölçmekte midir?

Okul müdürlerinin performans değerlendirmesi sürecine ilişkin öğretmen algılarını belirlemeye yönelik doğrudan geliştirilmiş bir ölçek bulunmamaktadır. Bu nedenle bu konu araştırılması gereken bir problem olarak görülmüştür. Böylelikle yeni performans değerlendirme sürecine ilişkin öğretmen algıları belirlenebilir, öğretmen değerlendirme yöntemlerine alternatif değerlendirme yaklaşımları geliştirilebilir, eğitim alanında kullanılan performans değerlendirme ölçütlerine katkıda bulunulabilir.

\section{Yöntem}

\section{1. Çalışma Grubu}

$\mathrm{Bu}$ araştırmada geliştirilmek istenilen "Okul Müdürlerinin Performans Değerlendirme Sürecine İlişkin Öğretmen Algıları" ölçeği Tekirdağ ilinin Çerkezköy ilçesinde görev yapan öğretmenlere uygulanmıştır. Bu araştırmanın çalışma grubuna; Çerkezköy ilçesinde bulunan ilkokul, ortaokul, lise ve anaokullarında görev yapan toplam 537 öğretmen dâhil edilmiştir.

Tablo 1. Çalışma Grubunda Yer Alan Öğretmenlerin Cinsiyete ve Mezun Oldukları Okula Göre Sayı ve Yüzdeleri

\begin{tabular}{llllll}
\hline Cinsiyet & & & \multicolumn{3}{c}{ Mezun olunan okul } \\
\hline & $\mathrm{n}$ & $\%$ & & $\mathrm{n}$ & $\%$ \\
\hline Kadın & 313 & 58.3 & Önlisans & 4 & .7 \\
Erkek & 224 & 41.7 & Lisans & 498 & 92.7 \\
& & & Yüksek lisans & 35 & .5 \\
\hline Toplam & 537 & 100 & Toplam & 537 & 100 \\
\hline
\end{tabular}


Tablo 1. İncelendiğinde, çalışma grubundaki öğretmenlerin \%58.3'ü kadın ( $\mathrm{n}=313)$ ve \%41.7'si erkektir $(\mathrm{n}=224)$. Mezun oldukları okula göre öğretmenlerin \%.7'si ön lisans mezunu( $\mathrm{n}=4)$, \%92.7'silisans mezunu $(n=498) \quad$ ve\% .5'i yüksek lisans mezunu $(n=35)$ olarak dağ 1 lım göstermektedir.

Tablo 2. Çalışma Grubunda Yer Alan Öğretmenlerin Branşlara Göre Dağılım Sayı ve Yüzdeleri

\begin{tabular}{lcclcc}
\hline Branş & $\begin{array}{c}\text { Öğretmen } \\
\text { sayısı (n) }\end{array}$ & $\begin{array}{c}\text { Yüzdeler } \\
\mathbf{( \% )}\end{array}$ & Branş & $\begin{array}{c}\text { Öğretmen } \\
\text { sayısı(n) }\end{array}$ & $\begin{array}{c}\text { Yüzdeler } \\
\text { (\%) }\end{array}$ \\
\hline Okulöncesi & 43 & 8 & İngilizce & 40 & 7.4 \\
Sınıf & 101 & 18.8 & Matematik & 50 & 9.3 \\
Din kültürü & 23 & 4.2 & Müzik & 10 & 1.8 \\
Türkçe & 39 & 7.2 & Kimya & 7 & 1.3 \\
Teknolojitasarım & 8 & 1.2 & Felsefe & 5 & .9 \\
Sosyal bilgiler & 19 & 3.5 & Fizik & 5 & .9 \\
Mesleki/teknik & 10 & 1.8 & Edebiyat & 25 & 4.6 \\
Fen ve teknoloji & 32 & 5.9 & Diğer & 100 & 18.6 \\
Rehberlik & 20 & 3.7 & & & \\
\hline
\end{tabular}

Tablo 2' ye göre, çalışma grubundaki öğretmenlerin, branşa göre dağılımlarında en fazla sınıf öğretmenleri(\%18.8), en az ise fizik (\%.9) ve felsefe (\%.9) branşındaki öğretmenler katılım sağlamıştır.

Tablo 3. Çalışma Grubunda Yer Alan Öğretmenlerin Hizmet Sürelerine Göre Sayı ve Yüzdeleri ve Okul düzeyine Göre Sayı ve Yüzdeleri

\begin{tabular}{|c|c|c|c|c|c|}
\hline Kidem yılı & $\begin{array}{l}\text { Öğretmen } \\
\text { sayısı (n) }\end{array}$ & $\begin{array}{l}\text { Yüzdeler } \\
(\%)\end{array}$ & Okul düzeyi & $\begin{array}{l}\text { Öğretmen } \\
\text { sayısı (n) }\end{array}$ & $\begin{array}{l}\text { Yüzdeler } \\
(\%)\end{array}$ \\
\hline $0-5$ Yil & 271 & 50.5 & Anaokulu & 19 & 3.5 \\
\hline 6-10Yil & 159 & 29.6 & İlkokul & 132 & 24.6 \\
\hline $11-15$ yıl & 61 & 11.4 & Ortaokul & 240 & 44.7 \\
\hline $16-20 \mathrm{Y}_{11}$ & 29 & 5.4 & Lise & 146 & 24.2 \\
\hline 21-25 Yil & 11 & 2.0 & & & \\
\hline $26+Y_{11}$ & 6 & 1.1 & & & \\
\hline Toplam & 537 & 100 & Toplam & 537 & 100 \\
\hline
\end{tabular}

Tablo 3 incelendiğinde öğretmenlerin hizmet sürelerine göre dağılımları; çalışma süresi 0-5 yıl aralığında olan \%50.5 (n=271), 6-10 yıl 
aras1 \%29.6 $(\mathrm{n}=159), 11-15$ y1l aras1 \%11.4 $(\mathrm{n}=61), 16-20$ yıl aras1 \%5.4 $(\mathrm{n}=29)$, 21-25 yıl arası \%2.0 $(n=11)$ ve 26 yıl üstü olan \%1.1(n=6) şeklindedir.Çalışmada hizmet yılı 0-5 yıl olan öğretmen sayısının diğerlerine oranla daha çok olduğu görülmektedir.Ayrıca, okul düzeyine göre dağılımlarında öğretmenlerin \%3.5' i anaokulunda ( $\mathrm{n}=19), \% 24.6$ 's1 ilkokulda $(\mathrm{n}=132), \% 44.7^{\prime}$ si ortaokulda $(\mathrm{n}=240)$ ve \%27.2'si lisede $(\mathrm{n}=146)$ çalıştığı görülmektedir.

\subsection{Veri Toplama Aracı}

$\mathrm{Bu}$ araştırmada, geliştirilen "Okul Müdürlerinin Performans Değerlendirme Sürecine İlişkin Öğretmen Algıları Ölçeği” deneme formu veri toplama aracı olarak kullanılmıştır. Verilerin toplanmasından önce ölçek geliştirme aşamaları incelenerek deneme formu oluşturulmuştur. Deneme formu hazır olduktan sonra Milli Eğitim Bakanlığı Tekirdağ ili Çerkezköy ilçesine bağlı okullarda uygulama yapılabilmesi için gerekli izinler alınmıştır. Toplamda 584 öğretmen uygulamaya katılmıştır, bunlar içinden eksik cevaplayan 47 öğretmenin ölçeği analiz dışı bırakılmıştır. Böylece araştırma kapsamında 537 öğretmenden toplanan veriler analiz edilmiştir. Ölçek geliştirmek için kullanılan ölçek geliştirme aşamaları sırasıyla şöyledir;

Tarama: Okul müdürlerinin performans değerlendirme sürecine ilişkin öğretmen algıları ölçeği geliştirilirken öncelikle alanyazın taranarak Türkiye'de ve yurtdışında kullanılan öğretmen performans değerlendirme sistemleri incelenmiştir.

Deneme formu ifadeleri için kaynak tarama: Ölçekte yer alacak olan ifadeleri belirlemek üzere MEB' de uygulanan değerlendirme sistemleri incelenmiştir. İnceleme yapılırken "Hangi ifadeler öğretmenlerin yeni değerlendirme sistemi hakkında algılarını açıklar ?" sorusuna da yanıtlar aranmıştır. Tarama sırasında 2016-2017 eğitim öğretim yılında uygulanan öğretmen performans değerlendirme kriterleri dikkate alınmıştır. Ayrıca öğretmen performans değerlendirme sistemi ile ilgili yazıll, basılı ve internet ortamındaki kaynaklar incelenmiştir. Bunun yanı sıra çeşitli branşlardan ve kıdem sahibi öğretmenler ile görüşülerek öğretmenlerin 
fikirleri alınmıştır. Ayrıca bu alandaki uzmanların görüşlerinden yararlanarak ölçek ifadeleri oluşturulmuştur.

Ífadelerin yazılması: İncelenen kaynaklar doğrultusunda altı bölüm altında toplam 70 madde yazılmıştır. Program ve planlama bölümünde toplam 10 madde, eğitim ve öğretim süreci bölümünde 11 madde, öğrenmeyi gelişimi izleme ve değerlendirme bölümünde 14 madde, okul aile ve toplum ilişkileri bölümünde 13 madde, kişisel ve mesleki değerler, mesleki gelişim bölümünde 12 madde, öğretmenlerin genel görüşleri bölümünde 10 madde bulunmaktadır. Ölçekte bulanacak ifadeler yazılırken her bir maddenin sadece tek ifade içermesine ve yazıldığı ana başlığa uygun olmasına dikkat edilmiştir. 70 maddenin 63 tanesi olumlu 7 tanesi olumsuz olarak düzenlenmiştir.

Uzman görüşü: Uzmanların görüşlerini almak için, ifadeler yazıldıktan sonra her alana ait ifadeler ayrı ayrı formlarda olmak üzere gruplandırılmıştır. Bu ifadeler Trakya Üniversitesi' nin Sosyal Bilimler Enstitüsü Eğitim Fakültesi Anabilim Dalında görev yapan sekiz akademisyene incelenmek üzere verilmiştir. Bu ifadelerle birlikte akademisyenlere çalışmanın amacı, kapsamı, ifadelerin özellikleri ve kendisinden beklenenlerin yer aldığı bir yönerge verilmiştir. Akademisyenlerden, alanlarını doğru olarak yansıtmayan ifadelerin çıkarılması, düzeltilmesi ya da gereken başka ifadelerin eklenmesi konusunda görüş istenmiştir ve uzmanlar için bir form oluşturulmuştur

Farklı branşlarda ve farklı okullarda çalışan 25 öğretmenden ölçekle ilgili oluşturulan ifadeleri değerlendirmeleri istenmiştir. Uygulama sonrası geri dönüt sağlayan yedi akademisyenden ve öğretmenlerden alınan görüşlere göre ifadeler, uygun şekilde tekrar düzenlenmiştir.

Ífadelerin ölçek formatına dönüştürülmesi: Uzman görüşleri doğrultusunda düzenlenen ifadeler ölçek formatına dönüştürülmüştür. Okul Müdürlerinin Performans Değerlendirme Sürecine İlişkin Öğretmen Algıları Ölçeği Uzman Formundan gelen görüşler arasında; bir ifadenin birden fazla algıyı ölçtüğü belirtilip bunların iki ayrı ifadeye çevrilmesi önerisi yer almıştır. Bu doğrultuda bazı maddeler iki ayrı ifade olarak düzenlenmiştir. Bazı maddelerde anlam açıklığı için düzeltmeler 
yapılmıştır. Ölçme aracında sırasıyla; fikrim yok, tamamen katılıyorum, katılıyorum, katılmıyorum ve kesinlikle katılmıyorum seçeneklerinden oluşan 5'li likert tipi dereceleme ölçeği kullanılmıştır Gerekli düzeltmelerden sonra 6 faktörde toplam 70 madde içeren ölçek formu oluşturulmuştur.

Kişisel bilgi bölümünün oluşturulması: Kişisel bilgiler bölümüne ölçek formunu cevaplayacak kişinin bilgilerini almak amacıyla sırasıyla, cinsiyet, mezun olunan okul, branş, kıdem yılı ve çalıştığı okul düzeyi ile ilgili maddelere yer verilmiştir.

Gerekli izinlerin alınması: Ölçek oluşturulduktan sonra araştırma önerisi, ölçek ve uygulama yapılmak istenen Tekirdağ ili Çerkezköy ilçesine ait okulların ismi yazılarak gerekli izinlerin alınması için Trakya Üniversitesi Eğitim Bilimleri Enstitüsü'ne verilmiştir. Gerekli yazışmaların ardından "uygulama yapılabilir" onayı alınmıştır.

Ölçeğin çoğaltılması: Gerekli izinler alındıktan sonra ve gerekli düzeltmelerin ardından ölçek çoğaltılarak beş sayfalık form oluşturulmuştur.

Ölçeğin uygulanması: İzin alınan okullardan uygulama için müdürlerle konuşup uygun zamanda uygulama aşamasına geçilmiştir. Öğretmenlere genel bir açıklama yapılıp gönüllü öğretmenlere ölçekler dağıtılıp cevaplamaları istenmiştir. Analize eksiksiz doldurulmuş olan ölçekler dâhil edilmiştir.

\subsection{Veri Analizi}

Ölçeğin uygulanması sonucunda, ölçeğe ilişkin faktör yapısını ortaya koymak amacıyla Açımlayıcı Faktör Analizi (AFA) ve Doğrulayıcı Faktör Analizi (DFA) kullanılmıştır. AFA için SPSS 15.0 (Statistical PackageFor Social Sciences) programından yararlanılarak analiz yapılmıştır. DFA için LISREL (LinearStructuralRelations) 8.80 istatistik paketi kullanılmıştır. Verilerin faktör analizinin varsayımlarından olan örneklem büyüklüğünün yeterliliği için KaiserMeyerOlkin (KMO) testi, çok 
değişkenli normalliğin sağlanıp sağlanmadığını ölçmek için Bartlett testi yapılmıştır. Yapılan testler sonucunda elde edilen değerler Tablo 4'te verilmiştir.

Tablo 4. KMO ve Bartlett Testi Sonuçları

\begin{tabular}{lll}
\hline $\begin{array}{l}\text { Kaiser-Meyer-Olkin (KMO) } \\
\text { Örneklem Yeterliliği }\end{array}$ & .93 \\
\hline Bartlett Anlamlılık Testi & Yaklaşık Kay-kare (x) & 19210.89 \\
& Serbestlik Derecesi (SD) & 2415 \\
& Anlamlılık Düzeyi (p) & .00 \\
\hline
\end{tabular}

Tablo $4^{\prime}$ te KMO değeri 93 düzeyinde olduğu görülmektedir. 0 ile 1 arasında değer alan KMO değeri .50-.70 arası normal, .70-.80 arasında iyi, $.80-.90$ arasında çok iyi ve .90 'nın üzerindeki değerler ise mükemmel olarak yorumlanmaktadır (Field, 2005). Bu durumda verilerin açımlayıcı faktör analizi yapmak için yeterli büyüklükte olduğu söylenebilir. Bartlett test sonucu $(p<.05)$ verilerin çok değişkenli normallik varsayımını sağladığını göstermektedir (Kaiser, 1974).

Ölçeğin faktör yapısını incelemek için ölçekte yer alan maddeler AFA tekniklerinden temel bileşenler analizi ile çözümlenmiştir. Temel bileşenler analizi çok sayıdaki değişkeni bilgi kaybına uğratmadan daha az sayıda değişkene indirgeyip, yorum yapabilme gücünü arttırdığı için tercih edilmiştir (Johnson ve Wichem, 1982). Faktörleri yorumlamak, açıklığını ve anlamlılığını sağlamak için dik döndürme tekniği kullanılmıştır. Değişken sayısını azaltarak en az maddeyle en çok bilgi toplayacak bir ölçme aracı geliştirmek için dik döndürme tekniklerinden varimaks yöntemi tercih edilmiştir (Can, 2014).

Modelin uygunluğunun test edilmesinde DFA'da Ki-Kare Uyum İndeksi $\left(\chi^{2} / \mathrm{df}\right)$, Standardize Edilmiş Ortalama Hataların Karekökü (SRMR), Yaklaşık Hataların Ortalama Karekökü (RMSEA), Karşılaştırmalı Uyum İndeksi (CFI) , Normlaştırılmış Uyum İndeksi (NFI) ve Normlaştırılmamış Uyum İndekslerine (NNFI) bakılmıştır. Ölçeğin Path modelinin kullanılmasıyla hem genel model hakkında istatistiksel bulgulara ulaşılmış, hem de değişkenler arasındaki etkileşimi daha bütünsel bir şekilde test etme olanağı sağlanabilmiştir. 
Ölçeğin ölçmek istediği değişkeni yeterli düzeyde ölçüp ölçmediğini belirlemek amaciyla düzeltilmiş madde-toplam korelasyonuna dayalı madde analizi ile toplam puana göre belirlenmiş üst \%27 ve alt \%27'lik grup ortalamaları farkına dayalı madde analizi yapılmıştır. Ayrıca ölçeğin güvenirliğini belirlemek için iç tutarlılık belirleme yöntemlerindenCronbach Alfa katsayısı kullanılmıştır.

\section{Bulgular ve Yorumlar}

$\mathrm{Bu}$ bölümde okul müdürlerinin performans değerlendirme sürecine ilişkin öğretmen algıları ölçeğinin geçerlik ve güvenirlik çalışmalarından elde edilen bulgular yer almaktadır.

\section{1. Ölçeğin Yapı Geçerliğine İlişkin Bulgular}

Ölçeğin analizine başlamadan önce ölçekte yer alan 64, 65, 66, 67, 68, 69, 70 numaralı maddelerin ölçeğin geneline göre olumsuz ifade içermelerinden dolayı bu maddeler için ters kodlama işlemi gerçekleştirilmiştir. Oluşturulan ölçeğin faktör yapısını belirleyebilmek için iki aşamalı yol izlenerek AFA ve DFA uygulanmıştır. Birinci aşamada AFA300 kişiden oluşan veriler ile yapılmıştır. Daha sonra AFA sonuçları dikkate alınarak 237 kişiden oluşan veriler üzerinden her faktöre ilişkin DFA işlemi uygulanmıştır.

İlk olarak ölçeğin faktör yapısını incelemek için ölçekte yer alan maddeler AFA ve faktörleri yorumlamak, anlamlılığını ve açılığını sağlamak için dik döndürme tekniği kullanılmıştır. Varimaks dik döndürme sonucunda elde edilen değerler Tablo 5'de verilmiştir.

İlk varimaks dik döndürme sonucunda ortaya çıkan ilk tabloda 12 faktörlü bir yapı elde edilmiştir. Aynı yapıyı ölçmeyen maddelerin ayıklanmasında en iyi ölçüt faktör yük değerinin .45 ve üzerinde olmasıdır (Büyüköztürk, 2003). Faktör örüntüsünün oluşturulmasında .30 ile .40 arasındaki değerlerin alt kesme noktası olarak alınabileceği belirtilmiştir (Tavşancıl, 2005). 
Tablo 5. Döndürülmüsş Bileşenler Matrisi

\begin{tabular}{|c|c|c|c|c|c|c|c|c|c|c|c|c|}
\hline & \multicolumn{12}{|c|}{ Bileşenler } \\
\hline & 1 & 2 & 3 & 4 & 5 & 6 & 7 & 8 & 9 & 10 & 11 & 12 \\
\hline Madde 4 & .78 & & & & & & & & & & & \\
\hline Madde 2 & .77 & & & & & & & & & & & \\
\hline Madde 5 & .76 & & & & & & & & & & & \\
\hline Madde 3 & .76 & & & & & & & & & & & \\
\hline Madde7 & .75 & & & & & & & & & & & \\
\hline Madde 1 & .69 & & & & & & & & & & & \\
\hline Madde 9 & .67 & & & & & & & & & & & \\
\hline Madde 6 & .65 & & & & & & & & & & & \\
\hline Madde10 & .61 & & & & & & & & & & & \\
\hline Madde 8 & .60 & & & & & & & & & & & \\
\hline Madde 29 & & .81 & & & & & & & & & & \\
\hline Madde 30 & & .77 & & & & & & & & & & \\
\hline Madde 27 & & .71 & & & & & & & & & & \\
\hline Madde 28 & & .70 & & & & & & & & & & \\
\hline Madde 26 & & .67 & & & & & & & & & & \\
\hline Madde 31 & & .65 & & & & & & & & & & \\
\hline Madde 34 & & .60 & & & & & & & & & & \\
\hline Madde 25 & & .60 & & & & & & & & & & \\
\hline Madde 33 & & .58 & & & & & & & & & & \\
\hline Madde 32 & & .57 & & & & & & & & & & \\
\hline Madde 35 & & .57 & & & & & & & & & & \\
\hline Madde 41 & & & & & & & & & & & & \\
\hline Madde 13 & & & .74 & & & & & & & & & \\
\hline Madde 15 & & & .70 & & & & & & & & & \\
\hline Madde 19 & & & .70 & & & & & & & & & \\
\hline Madde 16 & & & .69 & & & & & & & & & \\
\hline Madde 14 & & & .67 & & & & & & & & & \\
\hline Madde 17 & & & .66 & & & & & & & & & \\
\hline Madde 18 & & & .65 & & & & & & & & & \\
\hline Madde 12 & & & .62 & & & & & & & & & \\
\hline Madde 20 & & & .48 & & & & & & & & & \\
\hline Madde 21 & & & .48 & & & & & & & & & \\
\hline Madde 11 & .43 & & .47 & & & & & & & & & \\
\hline Madde 50 & & & & .77 & & & & & & & & \\
\hline Madde 54 & & & & .72 & & & & & & & & \\
\hline Madde 52 & & & & .67 & & & & & & & & \\
\hline Madde 53 & & & & .67 & & & & & & & & \\
\hline Madde 49 & & & & .65 & & & & & & & & \\
\hline Madde 51 & & & & .64 & & & & & & & & \\
\hline Madde 45 & & & & .60 & & & & & & & .48 & \\
\hline Madde 42 & & & & .52 & & & .51 & & & & & \\
\hline Madde 46 & & & & .51 & & & & & & & .50 & \\
\hline Madde 56 & & & & .48 & & .40 & & & & & & \\
\hline
\end{tabular}


Madde 44

Madde 66

Madde 67

Madde 70

Madde 65

Madde 69

Madde 68

Madde 64

Madde 58

Madde 57

Madde 59

Madde 55

Madde 60

Madde 48

Madde 47

Madde 43

Madde 61

Madde 62

Madde 63

Madde 37

Madde 38

Madde 39

Madde 36

Madde 40

Madde 24

Madde 23

Madde 22
.44

$$
.87
$$

.87

.86

.86

.81

.81

.80

.78

.78

.75

.59

Varimaks dik döndürme tekniği yapılan analizde faktör yükleri $.40^{\prime}$ in altında olan ve birden fazla faktörde birbirine yakın faktör yükleri veren binişik maddeler ölçekten çıkartılmıştır. Varimaks dik döndürme tekniği ölçekte binişik madde ve .40 altında madde kalmayıncaya kadar tekrarlanmıştır. Tekrarlanan dik döndürme işlemi sonucunda ölçekte toplam 10 madde sirasıyla en binişikten başlamak üzere $(11,41,62,60$, 56, $61,48,63,21,20)$ tek tek ölçekten çıkartılmıştır. Tekrar yapılan döndürme işlemleri sonunda ulaşılan en son hesaplanan değerler Tablo 6 ' da verilmiştir. 
Tablo 6.Tekrarlanan Döndürülmüş Bileşenler Matrisi

\begin{tabular}{|c|c|c|c|c|c|c|c|c|c|c|c|c|c|}
\hline Bileşenler & & & & & & & Bileşenler & & & & & & \\
\hline & 1 & 2 & 3 & 4 & 5 & 6 & & 1 & 2 & 3 & 4 & 5 & 6 \\
\hline Madde 27 & .76 & & & & & & Madde 47 & & .45 & & & & \\
\hline Madde 29 & .74 & & & & & & Madde 2 & & & .77 & & & \\
\hline Madde 26 & .73 & & & & & & Madde 4 & & & .76 & & & \\
\hline Madde 28 & .72 & & & & & & Madde 5 & & & .74 & & & \\
\hline Madde 34 & .71 & & & & & & Madde 3 & & & .74 & & & \\
\hline Madde 30 & .69 & & & & & & Madde 7 & & & .73 & & & \\
\hline Madde 25 & .69 & & & & & & Madde 1 & & & .67 & & & \\
\hline Madde 33 & .68 & & & & & & Madde 9 & & & .66 & & & \\
\hline Madde 35 & .66 & & & & & & Madde 6 & & & .63 & & & \\
\hline Madde 23 & .63 & & & & & & Madde 10 & & & .60 & & & \\
\hline Madde 32 & .63 & & & & & & Madde 8 & & & .58 & & & \\
\hline Madde 24 & .63 & & & & & & Madde 13 & & & & .71 & & \\
\hline Madde 22 & .62 & & & & & & Madde 19 & & & & .67 & & \\
\hline Madde 31 & .60 & & & & & & Madde 16 & & & & .67 & & \\
\hline Madde 45 & & .76 & & & & & Madde 15 & & & & .66 & & \\
\hline Madde 53 & & .71 & & & & & Madde 14 & & & & .66 & & \\
\hline Madde 37 & & .71 & & & & & Madde 18 & & & & .65 & & \\
\hline Madde 36 & & .70 & & & & & Madde 17 & & & & .64 & & \\
\hline Madde 52 & & .68 & & & & & Madde 12 & & & & .59 & & \\
\hline Madde 50 & & .68 & & & & & Madde 70 & & & & & .86 & \\
\hline Madde 54 & & .67 & & & & & Madde 67 & & & & & .86 & \\
\hline Madde 46 & & .65 & & & & & Madde 66 & & & & & .85 & \\
\hline Madde 51 & & .65 & & & & & Madde 65 & & & & & .85 & \\
\hline Madde 39 & & .63 & & & & & Madde 68 & & & & & .84 & \\
\hline Madde 38 & & .61 & & & & & Madde 69 & & & & & .83 & \\
\hline Madde 49 & & .61 & & & & & Madde 64 & & & & & .81 & \\
\hline Madde 44 & & .59 & & & & & Madde 57 & & & & & & .75 \\
\hline Madde 40 & & .56 & & & & & Madde 58 & & & & & & .73 \\
\hline Madde 42 & & .55 & & & & & Madde 59 & & & & & & .67 \\
\hline Madde 43 & & .46 & & & & & Madde 55 & & & & & & .55 \\
\hline
\end{tabular}

Tablo 6'ya bakıldığında araştırmada yer alan en düşük faktör yükü .45 ve en yüksek faktör yükü .86' dır . Bu sonuçlara göre ölçeğin maddeleri ile alt faktörün geçerliliğ̈i tespit edilmiştir.

Öz değerler grafiği incelendiğinde altı faktörün öz değerinin birin üzerinde olduğu görülmektedir (Şekil 1). 


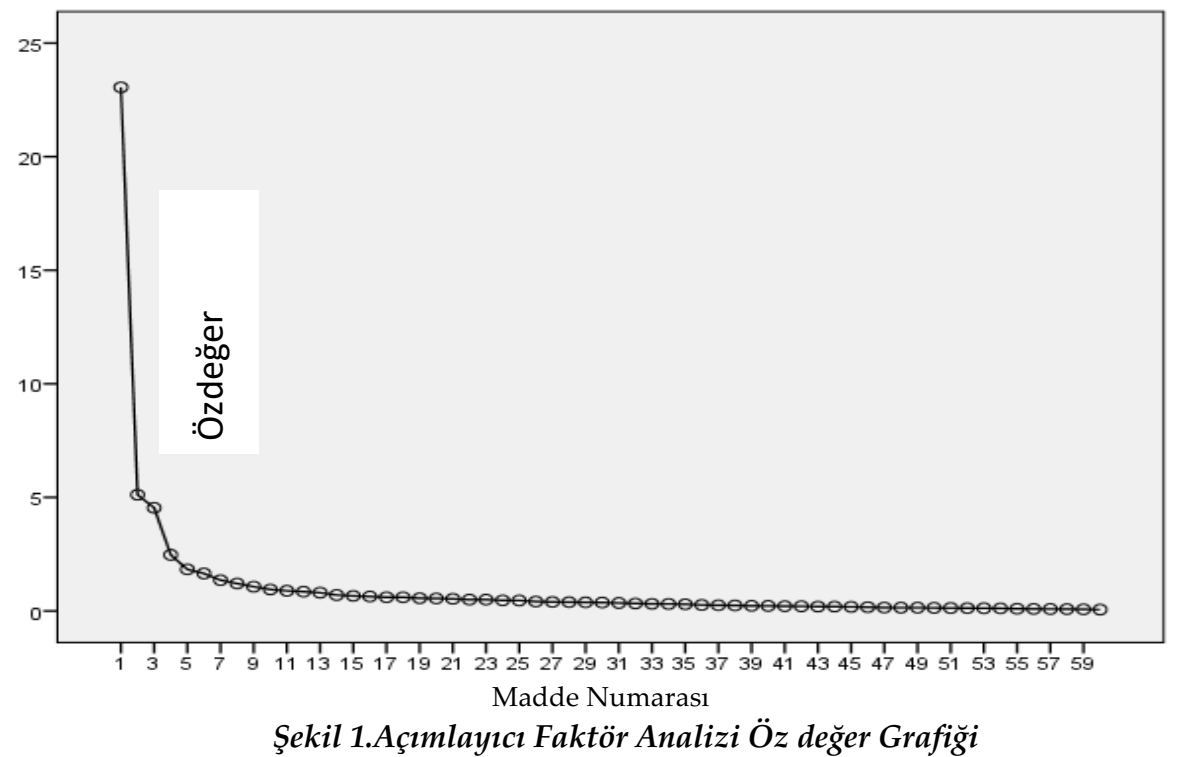

Ölçeğin öz değerler grafiği (screeplot) incelendiğinde altıncı faktöre kadar düşüşlerin belirgin olduğu; fakat bundan sonraki öz değer noktalarının üst üste binişik olduğu görülmektedir. Bu bulgu, öz değer tablosundaki altı faktörlü yapının aynı şekilde öz değer grafiğinde de altı faktörlü bir yapı olduğunu ortaya koymaktadır.

Önemli faktörlerin belirlenebilmesi için faktörlerin toplam varyansa yaptığ1 katkı incelenmelidir (Çokluk, Şekercioğlu ve Büyüköztürk, 2014). Ölçeğin faktörlerinin toplam varyansı açıklama yüzdesi ve açıklanan toplam varyans değerleri Tablo 7'de gösterilmiştir.

\section{Tablo 7. Açıklanan Varyans Değerleri}

\begin{tabular}{lllllll}
\hline & \multicolumn{2}{l}{ Özdeğer istatistiği } & \multicolumn{3}{l}{ Aç1klanan varyans } \\
\cline { 2 - 7 } 1 & Toplam & Varyans \% & Birikimli \% & Toplam & Varyans \% & Birikimli \% \\
\cline { 2 - 7 } 2 & 23.05 & 38.42 & 38.42 & 9.35 & 15.58 & 15.58 \\
3 & 5.11 & 8.52 & 46.94 & 9.12 & 15.20 & 30.79 \\
4 & 4.54 & 7.56 & 54.51 & 6.79 & 11.31 & 42.11 \\
5 & 2.46 & 4.11 & 58.62 & 5.22 & 8.70 & 50.81 \\
6 & 1.83 & 3.05 & 61.68 & 5.14 & 8.57 & 59.38 \\
\hline
\end{tabular}


Tablo 7' de açıklanan toplam varyans değerleri incelendiğinde, analize alınan 60 madde için altı faktör önerilmektedir (Çokluk, Şekercioğlu ve Büyüköztürk, 2014). Maddelerin, öz değeri birden büyük olan altı faktör altında toplandığ 1 görülmektedir. Ölçekteki birinci faktör toplam varyansın \%15.58'ini, ikinci faktör toplam varyansın \%15.20'sini, üçüncü faktör toplam varyansın \%11.31'ini, dördüncü faktör toplam varyansın $\% 8.70$ 'ini, beşinci faktör toplam varyansın $\% 8.57$ 'sini, altıncı faktör toplam varyansın \%5.04'ünü ve alt faktör birlikte toplam varyansın \%64.43'ünü açıklamaktadır. Faktör analizi neticesinde elde edilen varyans oranları ne denli yüksek olursa, bir ölçeğin faktör yapısı o denli güçlü olmaktadır. \%40-60 aralığında değişen varyans oranlarının sosyal bilimlerde ideal kabul edildiği (Yurdagül ve Bayrak 2012) ele alınırsa tabloya göre elde edilen \%64.43'lük varyans oranının yeterli olduğu söylenebilmektedir.

Doğrulayıcı Faktör Analizinde (DFA) modelin uygunluğunun test edilmesinde alanyazında sıklıkla kullanılan Ki-Kare/ Serbestlik Derecesi (Chi- Square / degrees of freedom, $\chi^{2} / \mathrm{df}$ ), Standardize Edilmiş Ortalama Hataların Karekökü (StandardizedRootMeanSquareResidual, SRMR), Yaklaşık Hataların Ortalama Karekökü (RootMeanSquareError of Approximation, RMSEA), Karşılaştırmalı Uyum İndeksi (Comparative Fit Index, CFI), Normlaştırılmış Uyum İndeksi (Normed Fit Index, NFI) ve Normlaştırılmamış Uyum İndeksi Non-normed Fit Index, NNFI) değerleri göz önünde bulundurulmuştur (Schermelleh-Engel, Moosbrugger ve Müller, 2003). Bu ölçütlerin sınır değerleri olarak Schermelleh-Engel, Moosbrugger ve Müller'in (2003) önerdiği değerler dikkate alınmıştır.

Doğrulayıcı faktör analizinde $\chi 2$ / df (ki kare/ serbestlik derecesi ) 2.49 olarak bulunmuştur. Bu değer modelin kabul edilebilir bir uyuma sahip olduğunu göstermektedir. Bu değerin 2 veya daha altında olması mükemmel uyuma, 5 veya daha altı bir değer olması ise kabul edilebilir bir uyuma sahip olduğunu belirtir (Sümer, 2000; Akt. Akgül, 2018). Modelin RMSEA değeri .07 olarak bulunmuştur ve bu durumda modelin kabul edilebilir uyuma sahip olduğu sonucuna ulaşılmıştır. SRMR uyum indeksinin .05 olduğu görülmektedir. Bu kapsamda elde edilen SRMR değerinin iyi uyuma karşılık geldiği söylenebilir. NFI değeri 95 iyi uyuma, NNFI değeri .97 iyi uyuma ve CFI değeri .97 iyi uyuma işaret etmektedir. Elde edilen veriler, araştırma kapsamında öğretmenlerin 
performans değerlendirme algılarını belirlemeye yönelik modelin iyi uyuma sahip olduğunu göstermektedir.

\section{Tablo 8. Ölçeğin Uyum İndeksleri ve Uyum İndekslerinin Kabul Sınırları}

\begin{tabular}{llll}
\hline Uyum İndeksleri & İyi Uyum & $\begin{array}{l}\text { Kabul Edilebilir } \\
\text { Uyum }\end{array}$ & $\begin{array}{l}\text { Ölçüm Modelinin } \\
\text { Sonuçları }\end{array}$ \\
\hline$\chi 2$ & $0 \leq \chi 2 \leq 2 \mathrm{df}$ & $2 \mathrm{df}<\chi 2 \leq 3 \mathrm{df}$ & 4224.57 \\
$\mathrm{p}$ değeri & $.05<\mathrm{p} \leq 1.00$ & $.01 \leq \mathrm{p} \leq .05$ & .00 \\
$\chi 2 / \mathrm{df}$ & $0 \leq \chi 2 / \mathrm{df} \leq 2$ & $2<\chi 2 / \mathrm{df} \leq 3$ & 2.49 \\
RMSEA & $0 \leq \mathrm{RMSEA} \leq .05$ & $.05<\mathrm{RMSEA} \leq .08$ & .07 \\
SRMR & $0 \leq \mathrm{SRMR} \leq .05$ & $.05<\mathrm{SRMR} \leq .10$ & .05 \\
NFI & $.95 \leq \mathrm{NFI} \leq 1.00$ & $.90 \leq \mathrm{NFI}<.95$ & .95 \\
NNFI & $.97 \leq \mathrm{NNFI} \leq 1.00$ & $.95 \leq \mathrm{NNFI}<.97$ & .97 \\
CFI & $.97 \leq \mathrm{CFI} \leq 1.00$ & $.95 \leq \mathrm{CFI}<.97$ & .97 \\
\hline
\end{tabular}

Okul müdürlerinin performans değerlendirme sistemine ilişkin öğretmen algılarını ölçmeye yönelik geliştirilen ölçeğin DFA Path diyagramı Şekil 2' de verilmiştir.

Gizli değişkenlerin gözlenen değişkeni açıklama durumlarına ilişkin $\mathrm{t}$ değerleri Şekil 2' de oklar üzerinde yer almaktadır. Parametre tahminleri; eğer $\mathrm{t}$ değerleri 1.96'yı aşarsa .05 düzeyinde, $2.56^{\prime} \mathrm{y}$ 1 aşarsa .01 düzeyinde anlamlıdır (Çokluk, Şekercioğlu ve Büyüköztürk, 2014). Ölçeğin DFA sonuçlarına ilişkin Path diyagramına göre tüm maddelerin $t$ değerlerinin .01 düzeyinde anlamlı olduğu görülmektedir.

“Okul Müdürlerinin Performans Değerlendirme Sürecine İlişkin Öğretmen Algıları Ölçeği” nin ölçtüğü özellik açısından kişileri ayırt etmede ne düzeyde yeterli olduğunu belirlemek amacı ile düzeltilmiş madde-toplam korelasyonuna dayalı madde analizi ve ölçekte toplam puana göre belirlenmiş üst \%27 ile alt \%27'lik grup ortalamaları farkına dayalı madde analizi yapılmıştır. 


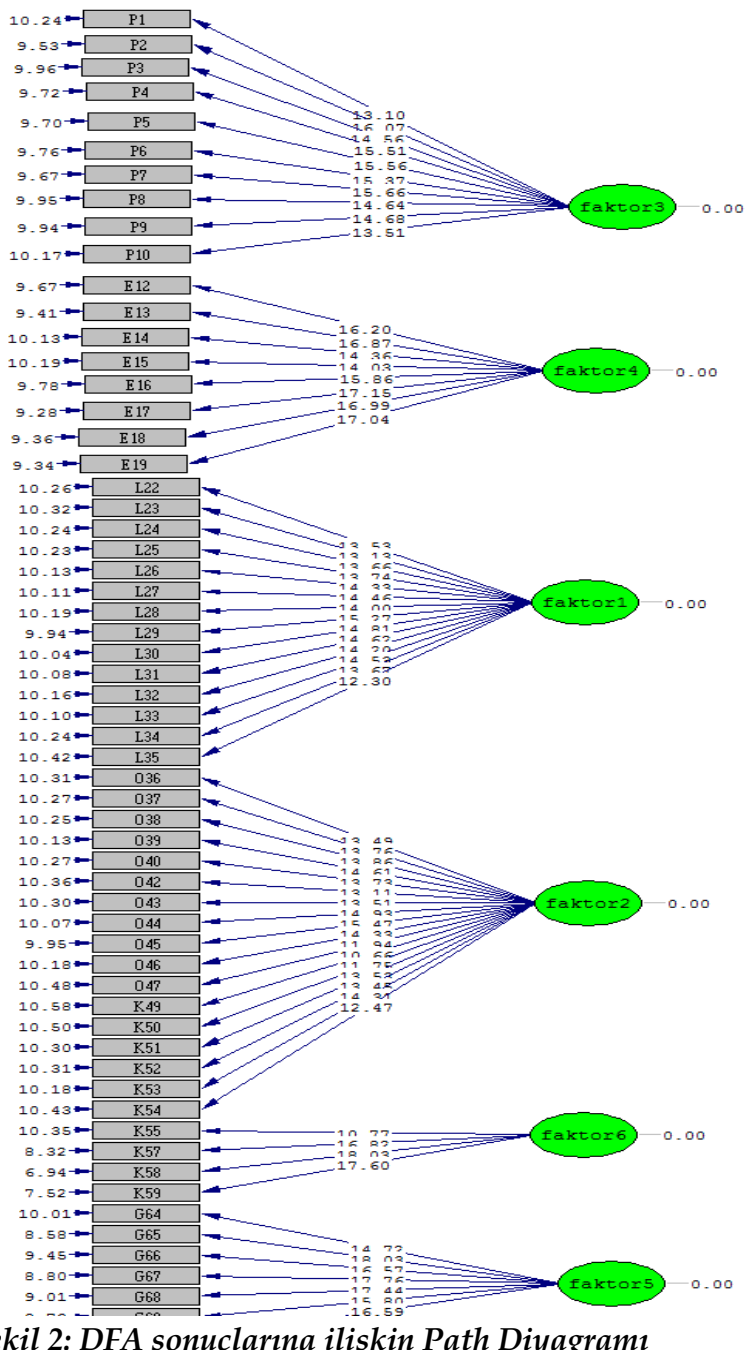

Şekil 2: DFA sonuçlarına ilişkin Path Diyagramı

Bu amaçla öğretmenlerin ölçekte yer alan ifadelere verdikleri cevaplara karşılık gelen değerlerin toplanmasıyla elde edilen ölçek puanları en yüksek puandan en düşük puana doğru sıralanmış ve 300 kişilik gruptan en düşük puanlara sahip 81 kişi alt grup, en yüksek puanlara sahip 81 kişi de üst grup olarak tanımlanmıştır. Ölçekte yer alan her bir maddeye ait madde puanı ile ölçekte yer alan tüm maddelere ait puanların toplamından oluşan düzeltilmiş madde toplam korelasyonları ile üst \%27 
ile alt \%27'lik grup ortalamaları arasındaki farklara ilişkin t testi sonuçları Tablo 9'da verilmiştir.

Tablo 9. Düzeltilmiş Madde Toplam Korelasyonları ve Üst \%27, Alt \%27 Puanları Arasindaki T-Testi

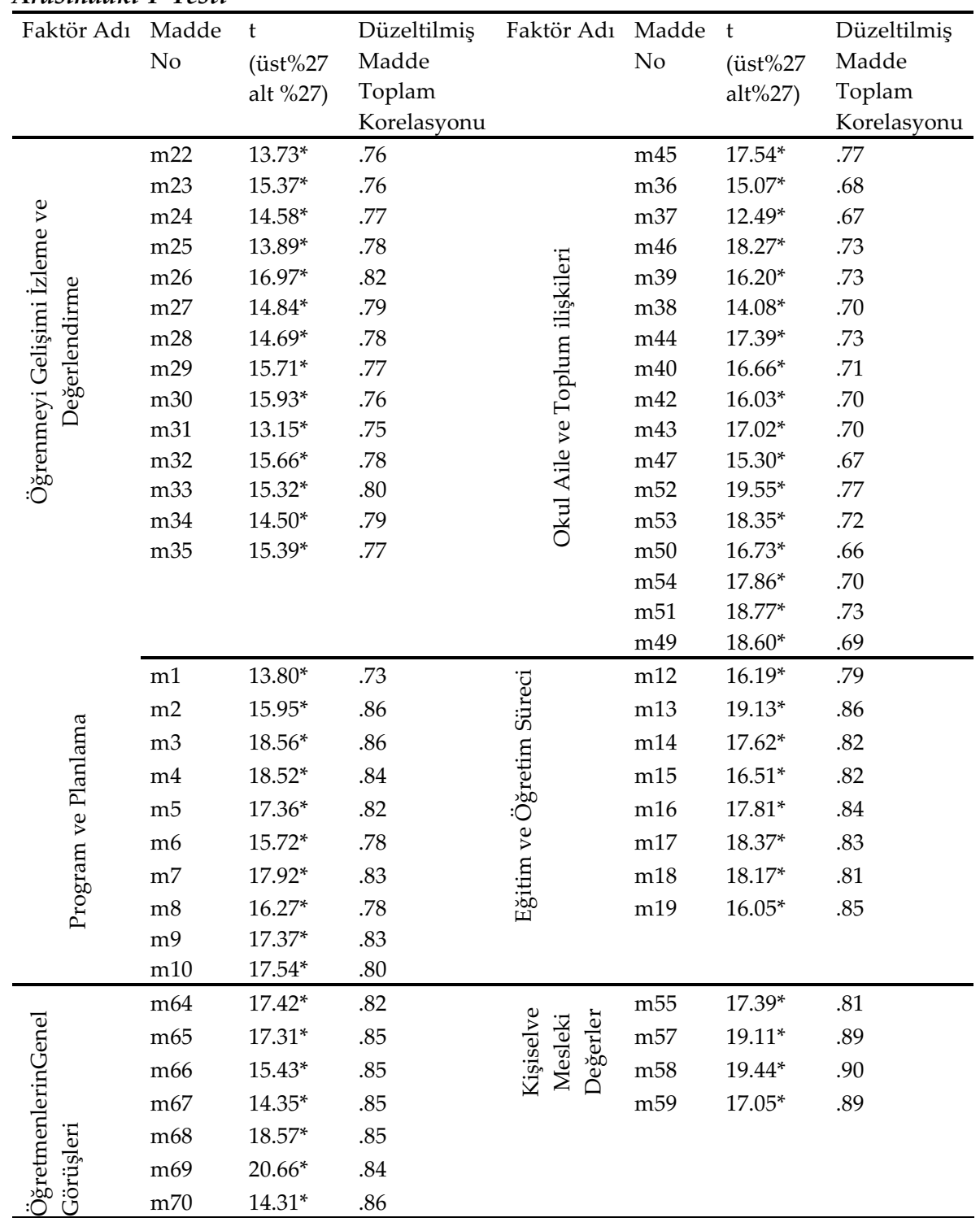

${ }^{*} p<.01$ 
Tablo 9'a göre, her maddeye ait olan madde toplam korelasyon katsayıları, .66 ile .90 arasında değişmektedir. Bu maddelere ait elde edilen katsayıların tümü .01 düzeyinde istatiksel olarak anlamlıdır. Elde edilen bu bulgu, ölçek kapsamında faktör analizi sonrası ölçekte yer alan maddelerin her birinin ölçtüğü özellik ile ölçeğin bir bütün olarak ölçtüğü özelliğin aynı olduğu şeklinde yorumlanabilir. Genel olarak, madde toplam korelasyonu .30 ve daha yüksek olan maddelerin çok iyi derecede ayırt edici olduğu söylenebilir (Büyüköztürk, 2003). Bu kriterden yola çıkarak ölçekte bulunan maddelerin ayırt ediciliklerinin oldukça yüksek olduğu görülmektedir. Tabloda verilen sonuçlara göre, alt ve üst \%27'lik gruplarda bulunan öğretmenlerin ölçekteki maddelere verdikleri cevapların puan ortalamalarının, tüm faktörler için .01 düzeyinde istatistiksel olarak anlamlı bir farklılık gösterdiği gözlenmektedir. Bu sonuçlar ışığında ölçekte yer alan altı alt faktörün olumlu ve olumsuz algıları ayırt edebildikleri kabul edilmiştir.

\section{2. Ölçeğin Güvenirliğine İlişkin Bulgular}

“Öğretmenlerin Okul Müdürlerinin Performans Değerlendirme Sürecine İlişkin Algıları Ölçeği" nin güvenirlik çalışması için, Cronbach alfa iç tutarlık katsayısı hesaplanmıştır. Cronbach alfa güvenirlik katsayıları Tablo 10' da verilmiştir.

Tablo 10. Ölçeğin Güvenirlik Analiz Sonuçları

\begin{tabular}{lll}
\hline \multicolumn{2}{l}{ Faktörler ve İsimleri } & Cronbach Alfa \\
\hline Faktör 1 & Öğrenmeyi Gelişimi İzleme ve Değerlendirme & .95 \\
Faktör 2 & Okul Aile ve Toplum ilişkileri & .94 \\
Faktör 3 & Program ve Planlama & .95 \\
Faktör 4 & Eğitim ve Öğretim Süreci & .94 \\
Faktör 5 & Öğretmenlerin Genel Görüşleri & .93 \\
Faktör 6 & Kişisel ve Mesleki Değerler & .90 \\
\hline & Ölçeğin Bütünü & .96 \\
\hline
\end{tabular}

Eğitim çalışmalarında .70 ve üzeri değerler, testin güvenirliği için yeterli kabul edilmektedir (Büyüköztürk, 2011). Ölçeğin iç tutarlılık 
katsayıları incelendiğinde ölçeğin tamamı için yüksek güvenirliğe sahip olduğu söylenebilir.

Ölçeğin nihai formu sırasıyla; Öğrenmeyi Gelişimi İzleme ve Değerlendirme (14 madde), Okul Aile ve Toplum ilişkileri (17 madde), Program ve Planlama (10 madde), Eğitim ve Öğretim Süreci (8 madde), Öğretmenlerin Genel Görüşleri (7 madde), Kişisel ve Mesleki Değerler (4 madde) biçiminde isimlendirilmiştir. Bu maddelerden 53 tanesi olumlu, 7 tanesi (madde 50, madde 51, madde 52, madde 53, madde 54, madde 55, madde 56) ise olumsuz maddelerdir. Ölçekte yer alan toplam 7 madde ölçeğin geneline göre olumsuz ifadeler içerdiğinden ters yönde puanlanmaktadır. Bu olumsuz maddeler 5. Faktör olan öğretmenlerin genel görüşleri altında toplanmıştır. Ölçeğin puanlanmasında cevaplara göre puan dağılımı şöyledir; fikrim yok 0 puan, tamamen katılıyorum 4 puan, katılıyorum 3 puan, katılmıyorum 2 puan, kesinlikle katılmıyorum 1 puan. Ölçeğin puanlamasında alınabilecek en düşük puan 0 en yüksek puan 219' dur. Birinci faktör öğrenmeyi gelişimi izleme ve değerlendirmede ulaşılabilecek en düşük puan 0 en yüksek puan 56; ikinci faktör okul aile ve toplum ilişkilerinde ulaşılabilecek en düşük puan 0 en yüksek puan 68; üçüncü faktör program ve planlamada ulaşılabilecek en düşük puan 0 en yüksek puan 40; dördüncü faktör eğitim ve öğretim sürecinde ulaşılabilecek en düşük puan 0 en yüksek puan 32; beşinci faktör öğretmenlerin genel görüşlerinde ulaşllabilecek en düşük puan 0 en yüksek puan 7; altıncı faktör kişisel ve mesleki değerlerde ulaşılabilecek en düşük puan 0 en yüksek puan 16' dır.

Yapılan analizler neticesinde ölçek kapsamında yer alan ifadelerin deneme formundaki madde numaraları, nihai ölçekteki maddelerin faktörlere göre dağılımı ve yeni madde numaraları Tablo $11^{\prime}$ de verilmiştir. 
Tablo 11. Ölçeğin Nihai Formunda Yer Alacak Maddelerin Deneme Formundaki Numaraları, Nihai Ölçekteki Yeni Numaraları ve Maddelerin Faktörlere Dă̆ılımı

\begin{tabular}{|c|c|c|}
\hline Yeni & Eski & \\
\hline Madde & Madde & Faktörler ve İfadeler \\
\hline \multirow[t]{3}{*}{ No } & No & \\
\hline & & Öğrenmeyi Gelişimi İzleme ve Değerlendirme \\
\hline & & Okul müdürüm; \\
\hline 1 & 22 & $\begin{array}{l}\text { Ölçme değerlendirme yöntem ve araçlarını, öğrenme süreçlerine uygun olarak } \\
\text { seçip seçmediğimi bilir }\end{array}$ \\
\hline 2 & 23 & $\begin{array}{l}\text { Ölçme ve değerlendirme aracının geçerliliği ve güvenirliğini, test edip } \\
\text { etmediğimi bilir. }\end{array}$ \\
\hline 3 & 24 & $\begin{array}{l}\text { Süreç odaklı, tamamlayıcı ölçme ve değerlendirme yöntem tekniklerini, kullanıp } \\
\text { kullanmadığımı bilir. }\end{array}$ \\
\hline 4 & 25 & $\begin{array}{l}\text { Ölçme ve değerlendirme süreçlerini, adil ve şeffaf biçimde yürütüp } \\
\text { yürütmediğimi bilir. }\end{array}$ \\
\hline 5 & 26 & $\begin{array}{l}\text { Ölçme sürecine ilişkin öğrencilerin kaygılarını giderici çalışmalar yapıp } \\
\text { yapmadığımı bilir. }\end{array}$ \\
\hline 6 & 27 & Öğrencilerin performans düzeylerini, düzenli olarak ölçüp ölçmediğimi bilir. \\
\hline 7 & 28 & Öğrencilerin gelişim düzeylerini, düzenli olarak ölçüp ölçmediğimi bilir. \\
\hline 8 & 29 & Öğrencilerin başarılarını, ödüllendirip ödüllendirmediğimi bilir. \\
\hline 9 & 30 & Öğrencilerin olumlu davranışlarını, ödüllendirip ödüllendirmediğimi bilir. \\
\hline 10 & 31 & $\begin{array}{llllll}\begin{array}{l}\text { Öğrencilerin olumsuz davranışları için yapıcı yönlendirmeler yapıp } \\
\text { yapmadığımı bilir. }\end{array} & & & \\
\end{array}$ \\
\hline 11 & 32 & Ölçme sonuçlarına göre gerektiği takdirde ek çalışmalar yapıp yapmadığımı bilir. \\
\hline 12 & 33 & $\begin{array}{l}\text { Bilgi ve iletişim teknolojilerini kullanarak değerlendirme sonuçlarını veliler ile } \\
\text { paylaşıp paylaşmadığımı bilir. }\end{array}$ \\
\hline 13 & 34 & $\begin{array}{l}\text { Bilgi ve iletişim teknolojilerini kullanarak değerlendirme sonuçlarını okul } \\
\text { yönetimi ile paylaşıp paylaşmadığımı bilir. }\end{array}$ \\
\hline \multirow[t]{3}{*}{14} & 35 & $\begin{array}{l}\text { Bilgi ve iletişim teknolojilerini kullanarak değerlendirme sonuçlarını, diğer } \\
\text { eğitimcilerle paylaşıp paylaşmadığımı bilir. }\end{array}$ \\
\hline & & Okul Aile ve Toplum ilişkileri \\
\hline & & Okul müdürüm \\
\hline 15 & 36 & Yöneticiler ile etkili iletişim kurup kurmadığımı bilir. \\
\hline 16 & 37 & Meslektaşlarımla etkili iletişim kurup kurmadığımı bilir. \\
\hline 17 & 38 & $\begin{array}{l}\text { Ĕ̆itim öğretimin kalitesini arttırmak için kişi kurum ve kuruluşlarla işbirliği } \\
\text { yapıp yapmadığımı bilir. }\end{array}$ \\
\hline 18 & 39 & $\begin{array}{l}\text { Eğitim öğretimin kalitesini arttırmak için aile katılımını sağlayıp sağlamadığımı } \\
\text { bilir. }\end{array}$ \\
\hline 19 & 40 & $\begin{array}{l}\text { Çevresel unsurları eğitim öğretimi düzenlemede destekleyici unsurlar olarak } \\
\text { dikkate alıp almadığımı bilir. }\end{array}$ \\
\hline 20 & 42 & $\begin{array}{l}\text { Ailelerin ilgi ve gereksinimleri doğrultusunda toplantı ya da seminerler } \\
\text { düzenleyip düzenlemediğimi bilir. }\end{array}$ \\
\hline 21 & 43 & $\begin{array}{l}\text { Öğrencinin gelişimi ile ilgili olarak ailelerle sürekli bilgi alışverişinde bulunup } \\
\text { bulunmadığımı bilir. }\end{array}$ \\
\hline 22 & 44 & $\begin{array}{l}\text { Ĕ̆itim öğretimde kalitenin arttırılması konusunda meslektaşlarımla işbirliği } \\
\text { yapıp yapmadığımı bilir. }\end{array}$ \\
\hline 23 & 45 & $\begin{array}{l}\text { Eğitim öğretim faaliyetlerini yürütürken öğretmenler kurulu kararlarını dikkate } \\
\text { alıp almadığımı bilir. }\end{array}$ \\
\hline
\end{tabular}




\begin{tabular}{|c|c|c|}
\hline 24 & 46 & $\begin{array}{l}\text { Eğitim öğretim faaliyetlerini yürütürken zümre kurul kararlarını dikkate alıp } \\
\text { almadığımı bilir. }\end{array}$ \\
\hline 25 & 47 & Okul dışında aile ile etkileşime geçip geçmediğimi bilir. \\
\hline 26 & 49 & Mesleki gelişimle ilgili seminerlere katılıp katılmadığımı bilir. \\
\hline 27 & 50 & Kılık kıyafetime özen gösterip göstermediğimi bilir \\
\hline 28 & 51 & Çocuk ve insan haklarını gözetip gözetmediğimi bilir \\
\hline 29 & 52 & $\begin{array}{l}\text { Milli, manevi, ahlaki ve evrensel değerlere uygun olarak davranıp } \\
\text { davranmadığımı bilir. }\end{array}$ \\
\hline 30 & 53 & $\begin{array}{l}\text { Türkçeyi kurallarına uygun akıcı ve anlaşılır biçimde kullanıp kullanmadığımı } \\
\text { bilir. }\end{array}$ \\
\hline \multirow[t]{3}{*}{31} & 54 & Beden dilimi doğru şekilde kullanıp kullanmadığımı bilir. \\
\hline & & Program ve Planlama \\
\hline & & Okul müdürüm; \\
\hline 32 & 1 & $\begin{array}{l}\text { Türk milli eğitim sisteminin amaç ve ilkelerini, planlara yansıtıp yansıtmadığımı } \\
\text { bilir. }\end{array}$ \\
\hline 33 & 2 & Planları, öğrenme ortamlarını dikkate alarak hazırlayıp hazırlamadığımı bilir. \\
\hline 34 & 3 & $\begin{array}{l}\text { Planları, öğrencilerin hazırbulunuşluk düzeylerine göre hazırlayıp } \\
\text { hazırlamadığımı bilir. }\end{array}$ \\
\hline 35 & 4 & $\begin{array}{l}\text { Planları, öğrencilerin bireysel farklılıklarını göz önünde bulundurarak hazırlayıp } \\
\text { hazırlamadığımı bilir. }\end{array}$ \\
\hline 36 & 5 & Planları, gerektiği durumlarda ihtiyaca göre güncelleyip güncellemediğimi bilir. \\
\hline 37 & 6 & Planları, zamanında uygulayıp uygulamadığımı bilir. \\
\hline 38 & 7 & $\begin{array}{l}\text { Öğrenme ortamlarını plandaki hedef kazanımların özelliklerine göre düzenleyip } \\
\text { düzenlemediğimi bilir. }\end{array}$ \\
\hline 39 & 8 & Öğrenme ortamlarında güvenliğe ilişkin tedbirleri, alıp almadığımı bilir. \\
\hline 40 & 9 & $\begin{array}{l}\text { Öğrenme ortamlarını, bireysel farklılıklara uygun olarak düzenleyip } \\
\text { düzenlemediğimi bilir. }\end{array}$ \\
\hline \multirow[t]{3}{*}{41} & 10 & $\begin{array}{l}\text { Öğrenme ortamının fiziksel koşullarını, (1sı, 1şık, ses durumu vb.) öğrenmeyi } \\
\text { destekleyecek biçimde düzenleyip düzenlemediğimi bilir. }\end{array}$ \\
\hline & & Eğitim ve Öğretim Süreci \\
\hline & & Okul müdürüm; \\
\hline 42 & 12 & $\begin{array}{l}\text { Ĕ̆itim öğretim sürecinin daha kalıcı olabilmesi için günlük yaşantılardan } \\
\text { örneklerle eğitim öğretim sürecini bütünleştirip bütünleştirmediğimi bilir. }\end{array}$ \\
\hline 43 & 13 & Öğrencilerin yaparak yaşayarak öğrenmelerini sağlayıp sağlamadığımı bilir. \\
\hline 44 & 14 & Eğitim öğretim teknolojilerini aktif şekilde kullanıp kullanmadığımı bilir. \\
\hline 45 & 15 & Eğitim öğretim sürecinde zamanı verimli şekilde kullanıp kullanmadığımı bilir. \\
\hline 46 & 16 & $\begin{array}{l}\text { Öğrencilerin bireysel yeteneklerini keşfedebilmelerine imkân sağlayıp } \\
\text { sağlamadığımı bilir. }\end{array}$ \\
\hline 47 & 17 & $\begin{array}{l}\text { Öğrencilerin ders içindeki zamanlarını etkili kullanmaları için yönlendirmeler } \\
\text { yapıp yapmadığımı bilir. }\end{array}$ \\
\hline 48 & 18 & $\begin{array}{l}\text { Öğrencilerin ders dışındaki zamanlarını etkili kullanmaları için yönlendirmeler } \\
\text { yapıp yapmadığımı bilir. }\end{array}$ \\
\hline \multirow[t]{3}{*}{49} & 19 & $\begin{array}{l}\text { Öğrencilere yapıcı, açılayıcı ve geliştirici geri bildirimler verip vermediğimi } \\
\text { bilir. }\end{array}$ \\
\hline & & Öğretmenlerin Genel Görüşleri \\
\hline & & Okul müdürümün; \\
\hline 50 & 64 & $\begin{array}{l}\text { Performansları değerlendirirken eğitim sendikalarını dikkate alarak puanlama } \\
\text { yaptığını düşünüyorum. }\end{array}$ \\
\hline
\end{tabular}




\begin{tabular}{|c|c|c|}
\hline 51 & 65 & $\begin{array}{l}\text { Performansları değerlendirirken cinsiyeti dikkate alarak puanlama yaptığını } \\
\text { düşünüyorum. }\end{array}$ \\
\hline 52 & 66 & $\begin{array}{l}\text { Performansları değerlendirirken kıdem yılını dikkate alarak puanlama yaptığını } \\
\text { düşünüyorum. }\end{array}$ \\
\hline 53 & 67 & $\begin{array}{l}\text { Performansları değerlendirirken kişinin memleketini dikkate alarak puanlama } \\
\text { yaptığını düşünüyorum. }\end{array}$ \\
\hline 54 & 68 & $\begin{array}{l}\text { Performansları değerlendirirken kişinin kendisi ile kişisel samimiyetini dikkate } \\
\text { alarak puanlama yaptığını düşünüyorum. }\end{array}$ \\
\hline 55 & 69 & $\begin{array}{l}\text { Performansları değerlendirirken kişinin karakter özelliklerini (sakin, baskın) } \\
\text { dikkate alarak puanlama yaptığını düşünüyorum. }\end{array}$ \\
\hline \multirow[t]{3}{*}{56} & 70 & $\begin{array}{l}\text { Performansları değerlendirirken çıkar ilişkisini dikkate alarak puanlama } \\
\text { yaptığını düşünüyorum. }\end{array}$ \\
\hline & & Kişisel ve Mesleki Değerler \\
\hline & & Okul müdürüm; \\
\hline 57 & 55 & $\begin{array}{l}\text { Mesleki duyarlılıklarımı arttırmak için sanat etkinliklerine katılıp katılmadığımı } \\
\text { bilir. }\end{array}$ \\
\hline 58 & 57 & Farklı uluslara karşı ayrımcılık yapıp yapmadığımı bilir. \\
\hline 59 & 58 & İnançlara karşı ayrımcılık yapıp yapmadığımı bilir. \\
\hline 60 & 59 & Bireylere karşı ayrımcılık yapıp yapmadığımı bilir. \\
\hline
\end{tabular}

*Ölçeğin son halinde yer alan maddeler, faktörlerine göre düzenlenmiştir.

\section{Sonuç ve Öneriler}

Araştırmanın amac1; 2015- 2016 eğitim öğretim yılında uygulanmaya başlanan okul müdürlerinin öğretmenlerin performansını değerlendirmesi üzerine öğretmenlerin bu sürece ilişkin algılarını ölçmek için geçerli ve güvenilir bir ölçek geliştirmektir.

Ölçek geliştirme aşamasında sırasıyla tarama, deneme formu ifadeleri için kaynak tarama, ifadelerin yazılması, uzman görüşlerinin alınması, ifadelerin ölçek formatına dönüştürülmesi, kişisel bilgi bölümünün oluşturulması, gerekli izinlerin alınması, ölçeğin çoğaltılması ve ölçeğin uygulanması işlemleri uygulanmıştır. Ölçme aracında; fikrim yok, tamamen katıliyorum, katıllyorum, katılmiyorum ve kesinlikle katılmıyorum seçeneklerinden oluşan $5^{\prime}$ likert tipi dereceleme kullanılmıştır.

Ölçeğin deneme formunda toplam 70 madde yer almıştır. Bunların; 63 tanesi olumlu 7 tanesi olumsuz ifade içermektedir. Veriler analize tabi tutulmadan önce ölçek içerisinde yer alan 64, 65, 66, 67, 68, 69, 70 numaralı 
maddelerin ölçeğin geneline göre olumsuz ifade içermelerinden dolayı söz konusu maddeler için ters kodlama işlemi gerçekleştirilmiştir.

Ölçeğin faktör yapısını ortaya koymak amacıyla AFA, DFA ve madde analizleri yapılmıştır. Ölçeğin güvenirliği için Cronbach alfa katsayısı hesaplanmiştır.

Örneklem büyüklüğünün yeterliği için KMO testi, çok değişkenli normalliğin sağlanıp sağlanmadığını test edebilmek için Bartlett testi yapılmıştır ve elde edilen değerler faktör analizi için uygun çıkmıştır.

Açımlayıcı faktör analizi neticesinde elde edilen varyans oranları ne denli yüksek olursa, bir ölçeğin faktör yapısı o denli güçlü olmaktadır. \%40-60 aralığında değişen varyans oranlarının sosyal bilimlerde ideal kabul edildiği (Yurdagül ve Bayrak, 2012) düşünülürse bu araştırma sonucunda elde edilen \%64,43'lük varyans oranın yeterli olduğu ortaya çıkmıştır.

DFA' da $\chi 2$ / df (ki kare/ serbestlik derecesi ) değerinin modelin kabul edilebilir bir uyuma sahip olduğunu göstermektedir. Elde edilen veriler, araştırma kapsamında öğretmenlerin performans değerlendirme algılarını belirlemeye yönelik elde edilen ölçüm modelinin iyi uyuma sahip olduğunu göstermektedir. DFA sonuçlarına ilişkin Path Diyagramına göre tüm maddelerin $t$ değerlerinin .01 düzeyinde anlamlı olduğu görülmüştür.

Ölçeğin faktör yapısını ortaya koyabilmek amacıyla yapılan AFA ve DFA sonucunda, 60 maddeden oluşan ölçeğin altı alt faktöre sahip olduğu sonucuna ulaşılmıştır. Madde analizinde madde toplam korelasyon katsayıları yüksektir. Maddelere ait elde edilen katsayıları anlamlı olarak farklılaşmıştır. Üst \%27 ile alt \%27'lik grup ortalamaları arasındaki farklara ilişkin $\mathrm{t}$ testi sonuçları, tüm faktörler için anlamlı farklılık göstermiştir. Bu sonuçlara göre çok faktörlü ölçekte bulunan altı alt faktörün olumlu ve olumsuz algıları ayırt edebildiği kabul edilmiştir.

Ölçeğin her alt faktörüne ait güvenirlik değerlerinin yüksek olması, her alt faktördeki maddelerin alt faktörün bütünüyle olan ilişkisinin yeterli olduğunu, ölçeğin iç tutarlılık anlamında güvenilir olduğunu göstermiştir. Ayrıca, ölçeğin maliyet ve zaman açısından ekonomik olması, uygulamasının ve cevaplanmasının pratik olması, ölçeğin kullanışlı olduğunu da göstermektedir. 


\section{2. Öneriler}

Öğretmen performans değerlendirmesi üzerine Türkiye'de çeşitli çalışmalar yapılmaktadır; fakat okul müdürlerinin öğretmen performansını değerlendirmesine ilişkin öğretmen algılarını belirlemeye yönelik çalışmalara ihtiyaç duyulmaktadır. Bu bölümde, gelecekte yapılacak araştırmalara ışık tutmak amacıyla bazı öneriler yer almaktadır:

Geliştirilen bu ölçek Tekirdağ ili dışında başka illerde, Türkiye genelinde uygulanabilir. Farklı örneklemler üzerinde incelenerek geçerlik ve güvenirlik analizleri yapılarak ölçeğin standardize edilmesi sağlanabilir.

Geliştirilen bu ölçek, okul müdürlerinin performans değerlendirmesine yönelik öğretmen algıları konusuyla ilgilenen araştırmacılara, bu tür konulara ilgi gösterenlere, eğitimcilere ve hatta yapılacak bu ve benzeri çalışmalar ile somut veriler elde edilmesine yardımcı olacaktır.

Öğretmenlerin okul müdürlerinin performans değerlendirmesine ilişkin algıları farklı yöntemlerle (yüz yüze görüşme, anket, röportaj) tespit edilebilir. Elde edilen sonuçlar ile geliştirilen ölçeğin uygulanmasından ortaya çıkan sonuçlar karşılaştııılabilir ve varsa farklılıklar araştırılabilir. Ayrıca, ölçeği okul müdürlerine uyarlayarak, okul müdürlerinin performans değerlendirme sistemi hakkındaki algılarını ölçen başka bir ölçek geliştirilebilir. 


\title{
EXTENDED ABSTRACT
}

\section{Teacher Perceptions Scale of School Principals on Performance Evaluation}

\author{
Ayşe Hünerli - Meltem Acar Güvendir \\ MONE - Trakya University
}

One of the basic elements of the education system, whose input is human and whose general purpose is to raise good people, is the teacher. Teachers who ensure that the student is shaped in all areas will be beneficial to their students as much as they can realize themself and contribute to school development. That is why it is so important for teachers to do their best, that is, to perform at the highest level. An effective performance evaluation system is an integral element of the development of teaching and learning (Kaçar, 2018). However, the question of whom, according to which criteria and how the teacher evaluation will be conducted has been uncertain for many years and continues to be discussed. (Koçak, 2016). 08.26.2014 Date of Turkey 'was abolished in control inspector. Although the audit of the institution continues to be carried out by the investigators, the inspectors will not be able to conduct regular course inspections, except when they deem necessary (Winter and Green, 2015).

According to article 54 of the Ministry of National Education Teacher Appointment and Relocation Regulation in the 2015-2016 academic year, teachers' performances in the academic year were evaluated by school principals. However, whether the evaluation process was carried out in accordance with its purpose has become an important discussion topic especially among teachers. In other words, the discussions about how effective, objective, impartial and sufficient equipment the school principals carry out this task have occupied the public (Argon and Ekinci, 2016). As a result of the researches conducted, it reveals the positive and negative aspects of the increase in the effectiveness of the principal in the teacher performance evaluation. The school principal has not received any special training for teacher supervision, but also that teachers are working colleagues, etc. such situations are seen as possible negative aspects of the supervision of the manager. Possibility of more frequent lesson checks, 
with teachers easily accessible by principals situations were stated as positive aspects of the managers' evaluation. (Winter and Green, 2015). There is no directly developed scale for determining teacher perceptions of school principals regarding performance evaluation process. Therefore, this issue has been seen as a problem that needs to be investigated. Thus, the perceptions of teachers related to the performance evaluation process of school principals can be determined, contribution can be made to the performance evaluation criteria used in the field of education, alternative evaluation approaches to teacher evaluation methods can be developed.

Purpose of the research; to develop a valid and reliable scale to measure teachers' perceptions of this process upon school principals' evaluation of teachers' performance.

\section{Method}

During the development phase of the scale, the procedures for screening for the test form statements, writing expressions, getting expert opinions, converting the expressions into scale format, creating the personal information section, obtaining the necessary permissions, reproducing the scale and applying the scale were applied. In the measuring tool; I have no idea, I totally agree, I agree, I disagree, and I definitely disagree Likerttype grading, which consists of 5 options, is used. To the study group of this research; 537 teachers working in kindergarten, primary, secondary and high school institutions in Çerkezköy district are included.

Exploratory Factor Analysis (AFA) and Confirmatory Factor Analysis (CFA) were performed for the construct validity of the data obtained as a result of the application of the scale. Analysis was performed using the SPSS 15.0 (Statistical Package For Social Sciences) program for AFA. LISREL (Linear Structural Relations) 8.80 statistics package was used for DFA.

In order to determine that the scale adequately measures the variable that it wants to measure, the item analysis based on the difference between the upper $27 \%$ and the lower $27 \%$ group averages determined according to the total score was made with the item analysis based on the corrected item-total correlation. Cronbach Alfa, one of the internal consistency determination methods, was used to examine the reliability of the scale. 


\section{Findings and Comments}

The KMO test was used for the adequacy of the sample size and the Bartlett test was performed to test whether multivariate normality was achieved and the values obtained were suitable for factor analysis.

With the "Basic Components Analysis", which is one of the AFA techniques, and the vertical rotation technique was used to interpret the factors, to ensure their significance and clarity, as a result of the vertical rotation process, a total of 10 items in the scale start from the most overlapping $(11,41,62,60,56,61,48,63,21,20)$ was individually subtracted from the scale.

The higher the variance rates obtained as a result of factor analysis, the stronger the factor structure of a scale. Considering that variance rates ranging between $40-60 \%$ are considered ideal in social sciences (Yurdagül, 2012), it can be said that the variance rate obtained as a result of this research is sufficient. In DFA, RMSEA value is .07 SRMR value is .05, NFI value is $.95 \mathrm{NNFI}$ value is $.97 \mathrm{CFI}$ value is.97. The data obtained shows that the model for determining teachers' perceptions of performance evaluation within the scope of the research is in good agreement.

According to the Path Diagram regarding the CFA results, it was determined that $t$ values of all items were significant at the 01 level. It can be interpreted that the construct validity of the scale is sufficient.

When the T test analysis results are analyzed, it is observed that the average of the scores of the teachers' answers in the lower and upper 27\% groups for items showed a statistically significant difference at the level of .01 for all dimensions. The high Cronbach alpha reliability values of each sub-dimension of the scale showed that the relationship of each subdimension with the whole sub-dimension was sufficient and the scale was reliable in terms of internal consistency.

\section{Conclusion and suggestions}

As a result; A valid and reliable 6-factor measurement tool consisting of 60 items was developed to determine the perceptions of teachers about school principals' performance evaluation process. 
Suggestions;

- Developed this scale in other provinces outside the province of Tekirdağ, Turkey applied in general. The scale can be standardized by analyzing validity and reliability by analyzing different samples.

- This scale will help researchers interested in teacher perceptions of school principals' performance evaluation, interest in such subjects, educators and even obtain concrete data with these and similar studies.

- Teachers 'perceptions of school principals' performance evaluation can be determined by different qualitative methods (face to face interview, questionnaire, interview). The results obtained from the application of the developed scale can be compared and if any, the differences can be investigated.

- By adapting the scale to school principals, a scale that measures the perceptions of school principals about the performance evaluation system can be developed.

\section{Kaynakça / References}

Akgül, M. Ş. (2018). Illkokul 3. ve 4. Sınıföğrencilerinin çocuk hakları konusundaki bilinç düzeylerinin belirlenmesi: Bir ölçek geliştirme çalışması (Yayımlanmamış Yüksek Lisans Tezi). Ondokuz Mayıs Üniversitesi, Eğitim Bilimleri Enstitüsü, Samsun.

Balyer, A. (2012). Çağdaş okul müdürlerinin değişen rolleri. Ahi Evran Üniversitesi Kirşehir Ĕ̆itim Fakültesi Dergisi, 13(2), 75-93.

Bülbül, T., Acar Güvendir, M., Tunç, B. ve Özdem, G. (2015) Yönetim uygulamaları ölçeğinin türkçeye uyarlanması, Sakarya Üniversitesi Eğitim Fakültesi Dergisi, (29) 121-141.

Büyüköztürk, Ş.(2003). Bilimsel araştırma yöntemleri. Ankara: Pegem Yayınları.

Büyüköztürk, Ş. (2011). Sosyal bilimler için veri analizi el kitabl: İstatistik, araştırma deseni, SPSS uygulamaları ve yorum (15. baskı). Ankara: Pegem Yayınları.

Can, A. (2014). Spss ile Bilimsel Araştırma Sürecinde Veri Analizi, Ankara: Pegem Akademi Yayıncilı. 
Çokluk, Ö. Şekercioğlu, G. ve Büyüköztürk, Ş. (2014). Sosyal bilimler için çok değişkenli istatistik spss ve lisrel uygulamaları (3. Baskı). Ankara: Pegem Akademi.

Fırıncıoğulları Bige, E. (2014). İlkokul müdürlerinin ders denetimleri ile ilgili öğretmen görüşleri (Yayımlanmamış Yüksek Lisans Tezi). Adnan Menderes Üniversitesi, Sosyal Bilimler Enstitüsü, Aydın.

Gür Erdoğan, D. ve Horzum, M. B. (2019). Öğretmen gelişim modeli öğretmen performansı üzerine değerlendirme. Siyaset, Ekonomi ve Toplum Araştırmaları Vakfı (SETA) Raporu.

Johnson, R. A. ve Wichern, D. W. (1982). Applied multivariate statistical analysis. New Jersey: PrenticeHall, Inc.

Kış, A. ve Yeşil, D. (2015). Okul müdürlerinin ders denetimine ilişkin öğretmen görüşlerinin incelenmesi. İnönü Üniversitesi Eğitim Bilimleri Enstitüsü Dergisi, 2(3), 27-45.

MEB. (2015). Millî Eğitim Bakanlığı Öğretmen Atama Ve Yer Değiştirme Yönetmeliği, 29329 Sayılı Resmi Gazete.

MEB-EARGED. (2001). Öğretmenlerin performans değerlendirme modeli ve sicil raporları. Ankara: Milli Eğitim Basımevi.

MEB-EARGED. (2006). Okulda performans yönetimi modeli. Ankara: Milli Eğitim Basımevi.

MEB, Teftiş Kurulu Başkanlığı, Van Koç İlköğretim Okulu Denetim ve Performans Değerlendirme Bilgilendirme Toplantısı Sunuları. Edinildiği Tarih: 16.04.2018.

Meşeci, F. (2007). İngiltere'de ilköğretim performans değerlendirme sistemi ve Türkiye için öneriler. Değerler Eğitimi Dergisi. 5 (14), 79-105.

Özmen, F. ve Batmaz, C. (2004). Illköğretim okul müdürlerinin öğretmen denetimindeki etkililikleri- cinsiyet ve yaş değişkenine göre öğretmen görüşleri. XIII. Ulusal Eğitim Bilimleri Kurultayı, İnönü Üniversitesi, Eğitim Fakültesi, Malatya

Özmercan, C. (2016). Performans değgerlendirme sistemleri ve sürdürülebilir performans: milli eğitimde bir uygulama. (Yayımlanmamış Yüksek Lisans), Karabük Üniversitesi, Sosyal Bilimler Enstitüsü, Karabük.

Sezgin, F., Tinmaz, A., ve Tetik, S. (2017). Performans kriterlerine göre öğretmenlerin değerlendirilmesine ilişkin okul müdürü ve öğretmen görüşleri. Journal of Human Sciences, 14(2), 1647-1668.

Sabuncuoğlu, Z. (2013). Uygulama örnekleriyle insan kaynaklarn yönetimi, İstanbul: Beta Basım Yayın Dağıtım A.Ş. 
Sakıcı, A. E. (2011). Öğretmenlerin performansa dayalı değerlendirilmesinde uygulanabilecek ölçütlere ilişkin görüşleri. (Yayımlanmamış Yüksek Lisans Tezi). Eskişehir Osmangazi Üniversitesi, Eğitim Bilimleri Enstitüsü, Eskişehir.

Schermelleh-Engel, K., Moosbrugger, H. veMüller, H. (2003). Evaluatingthe fit of structural equation models: Tests of Significance and Descriptive Goodness-of-Fit Measures. Methods of Psychological Research, 8(2), 2374.

Soydan, T. (2012). Eğitim alanında performans değerlendirme sisteminin geçerliği üzerine yönetici ve öğretmen görüşlerine dayalı bir araştırma. Ege Eğitim Dergisi 13(1), 1-251.

Sürer, M. (2016). Öğretmenlerin performans değerlendirme kriterlerine göre kendilerini değerlendirmeleri (Denizli ili çal ilçe örneği). (Yayımlanmamış Yüksek Lisans Tezi). Pamukkale Üniversitesi, Eğitim Bilimleri, Denizli.

Süzen, A. Z. (2007). İnsan kaynaklar yönetim süreçleri çerçevesinde öğretmen değerlendirmesinde performans değerlendirme; özel bir ilköğretim okulundaki sını öğretmenlerinin görüşü. (Yayımlanmamış Yüksek Lisans Tezi). Eskişehir Anadolu Üniversitesi, Eğitim Bilimleri Enstitüsü, Eskişehir.

Şengül, Y. (2010). Illköğretim okulu yönetici ve öğretmenlerinin 360derece performans değerlendirme sistemine ilişkin görüşleri. (Yayımlanmamış Yüksek Lisans Tezi). Samsun Ondokuz Mayıs Üniversitesi, Sosyal Bilimler Enstitüsü, Samsun

Tavşancıl, E. (2005). Tutumları ölçme ve SPSS ile veri analizi. Ankara: Pegem Yayınları.

Yılmaz, K. (2009). Okul müdürlerinin denetim görevi, İnönü Üniversitesi Eğitim Fakültesi Dergisi, 10(1), 19-35.

Yurdagül, H. ve Bayrak, F. (2012). Ölçek geliştirme çalışmalarında kapsam geçerlik ölçüleri: Kapsam geçerlik indeksi ve Kappa istatistiğinin karşılaştırılması. Hacettepe Üniversitesi Ĕ̆itim Fakültesi Dergisi, 2, 264271. 


\section{Kaynakça Bilgisi / Citation Information}

Hünerli, A. ve Acar-Güvendir, A. (2021). Okul müdürlerinin performans değerlendirme sürecine ilişkin öğretmen algıları ölçeği. OPUSUluslararası Toplum Araştırmaları Dergisi, 18(38), 5091-5124. DOI: 10.26466/opus.801411. 